\title{
Cloning and sequencing the endocarditis immunodominant antigen of Streptococcus sobrinus strain MUCOB 263
}

\author{
W. BROOKS and J. P. BURNIE* \\ Department of Medical Microbiology, University of Manchester Medical School, Oxford Road, Manchester M13 9PT
}

\begin{abstract}
Summary. Immunoblotting sera from cases of Streptococcus mutans or S. sobrinus endocarditis against an extract from $S$. sobrinus strain MUCOB 263 had identified three immunodominant antigenic bands at 190, 200 and $220 \mathrm{kDa}$. A lambda ZAPII DNA library was produced from the sheared genomic DNA of S. sobrinus MUCOB 263 and six identical positive clones were identified when this library was screened with serum from a patient with endocarditis caused by a bacterium from the mutans group of streptococci. On subcloning and sequencing, a protein containing 1548 amino acids was identified with a $99 \cdot 2 \%$ homology to the SpaA antigen of S. sobrinus and $68.4 \%$ homology to the PAc antigen of $S$. mutans.
\end{abstract}

\section{Introduction}

Infective endocarditis remains an important disease in patients with underlying rheumatic or congenital heart valve lesions. Previous work has shown that antibody to streptococcal antigens is raised in streptococcal endocarditis and produces a pattern on immunoblot which is species specific. ${ }^{1}$ In the case of Streptococcus sobrinus, patients with active endocarditis produced antibody to bands at 220,200 and $190 \mathrm{kDa}$. These antigens have not been identified, but an antigen alternatively called antigen $\mathrm{B},{ }^{2} \mathrm{I} / \mathrm{II},{ }^{3} \mathrm{IF},{ }^{4}$ MSL- $1,{ }^{5} \mathrm{P}^{6}{ }^{6}$ or PAc, ${ }^{7}$ has been implicated in the development of dental caries. This antigen has an apparent mol. wt of $185 \mathrm{kDa}^{2}$

The purpose of this work was to clone the immunodominant antigens of $S$. sobrinus strain MUCOB 263 and thereby ascertain their identity. This was done by preparing a library in the expression vector lambda ZAPII and screening the library with serum from a patient with active endocarditis. The aim was to find out whether one of the endocarditis-specific antigens of $S$. sobrinus is related to antigen I/II. This is important, as antigen I/II has been used successfully as an anti-caries vaccine in Rhesus monkeys ${ }^{8}$ and antibody against it has been shown to cross-react with heart tissue. ${ }^{4}$

This approach was preferred to the identification of an antigen from a gel by direct amino-acid sequencing, as several proteins may run on the same place on the gel and this may be misleading. Antibody selection of the antigen in an expression system avoids this

Received 17 Sept. 1993; accepted 9 Nov. 1993.

* Correspondence should be sent to Professor J. P. Burnie. problem and also preferentially detects linear epitopes. These might be synthesised subsequently and form the basis of a test to detect endocarditis-specific antibody without the need for immunoblotting.

\section{Materials and methods}

\section{$D N A$ isolation and lambda ZAPII library preparation}

$S$. sobrinus strain Manchester University Collection of Bacteria No. 263 (MUCOB 263) was used both here and in the previous immunoblotting paper. ${ }^{1}$ Initially, strain MUCOB 263 was identified as $S$. mutans, a fact reflected in the aforementioned paper. However, more detailed testing of this strain revealed that MUCOB 263 is biochemically more similar to $S$. sobrinus (Professor D. Bratthall, personal communication). To avoid future confusion, the organism has now been renamed S. sobrinus MUCOB 263. DNA was isolated essentially by the method described by Chassy. ${ }^{9}$ Bacterial cells were grown overnight at $37^{\circ} \mathrm{C}$ with shaking in brain-heart infusion broth containing glucose $0.2 \%$ and $40 \mathrm{mM} \mathrm{D}$, L-threonine (Sigma). The bacteria were harvested by centrifugation at $5000 \mathrm{rpm}$ for $10 \mathrm{~min}$ before being washed and resuspended in $12.5 \mathrm{ml}$ of $0.02 \mathrm{M}$ Tris, $\mathrm{pH} 8.2 ; 25 \mathrm{ml}$ of $20 \mathrm{M}$ polyethylene glycol (PEG) $24 \%$ in distilled water were then added and mixed. Lysozyme was added at $34.6 \mathrm{mg} / \mathrm{ml}$, equivalent to $100 \mu \mathrm{g} /$ unit obtained by measuring the OD600 of a 10-fold dilution of bacterial cultures. After incubation for $1 \mathrm{~h}$ at $37^{\circ} \mathrm{C}$, the spheroplasts formed were centrifuged at $5000 \mathrm{rpm}$ for $10 \mathrm{~min}$ and thoroughly resuspended in $50 \mathrm{ml}$ of $10 \mathrm{~mm}$ Tris-Cl, pH 8.0, 1 mM EDTA (TE). The spheroplasts were lysed with $5.5 \mathrm{ml}$ of sodium dodecyl sulphate (SDS) 
$10 \%$, at $60^{\circ} \mathrm{C}$ for $15 \mathrm{~min}$. The DNA was purified by standard procedures, ${ }^{10}$ treated with RNAase A (Sigma) (after pre-boiling the RNAase at $100^{\circ} \mathrm{C}$ for $15 \mathrm{~min}$ ), treated with proteinase $\mathrm{K}$, extracted with phenol:chloroform:isoamyl-alcohol $(25: 24: 1)$ and precipitated with ethanol. Plasmid DNA was removed by ethanol precipitation in the presence of $0.3 \mathrm{M}$ ammonium acetate, $\mathrm{pH} 5 \cdot 2$. Further purification was achieved by dialysis against TE over $36 \mathrm{hr}$ at $4^{\circ} \mathrm{C}$.

The lambda ZAPII library with an insert size range of $2-7 \mathrm{~kb}$ was prepared by Clontech Laboratories Inc., Cambridge Biosciences. The DNA was sheared mechanically, EcoRI linkers were added, the DNA was fractionated, and inserts were ligated into the lambda ZAPII vector arms.

\section{Antibody screening}

Serum was taken from the patient with $S$. mutans endocarditis described previously ${ }^{1}$ and used for antibody screening. Escherichia coli XL1-Blue cells were infected with the lambda ZAPII phage on L broth agar (bacto-tryptone $10 \mathrm{~g} / \mathrm{L}$, yeast extract $5 \mathrm{~g} / \mathrm{L}$, $\mathrm{NaCl} 10 \mathrm{~g} / \mathrm{L}$, maltose $2 \mathrm{~g} / \mathrm{L}$, bacto-agar $15 \mathrm{~g} / \mathrm{L}$ ) at $c$. $3000 \mathrm{pfu} / 85-\mathrm{mm}$ plate. This was incubated at $42^{\circ} \mathrm{C}$ for $3 \mathrm{~h}$. Plaques were transferred to nitrocellulose filters $(0.45 \mu \mathrm{m}$ pore size; Sartorius AG, Goettingen, Germany), impregnated with $10 \mathrm{~mm}$ isopropyl $\beta$-D-thiogalactopyranoside (IPTG), at $37^{\circ} \mathrm{C}$ for $2 \mathrm{~h}$. These filters were blocked overnight at $4^{\circ} \mathrm{C}$ with bovine serum albumin (BSA; Sigma) $3 \%$ in buffered saline (150 mM NaCl, $10 \mathrm{~mm}$ Tris). Serum, diluted 100 -fold in BSA $3 \%$, was added to the filters and incubated at room temperature for $2 \mathrm{~h}$. The filters were then washed for $30 \mathrm{~min}$ in washing solution $(150 \mathrm{mM} \mathrm{NaCl}$, Tween $200.05 \%$ ), before the second antibody, anti-human IgG conjugated to alkaline phosphatase (Sigma) diluted 1000-fold in BSA 3\%, was added. After $1 \mathrm{~h}$ at room temperature, the filters were again washed and stained with equal volumes of naphthol ASMX phosphate $(0.4 \mathrm{mg} / \mathrm{ml}$ in distilled water; Sigma) and Fast Red TR salt $(6 \mathrm{mg} / \mathrm{ml}$ in $0.2 \mathrm{M}$ Tris, $\mathrm{pH} 8.2$; Sigma) (the Fast Red stain). Positive plaques were transferred to $1 \cdot 5-\mathrm{ml}$ tubes containing $200 \mu \mathrm{l}$ of SM $(100 \mathrm{~mm}$ $\mathrm{NaCl}, 50 \mathrm{~mm}$ Tris- $\mathrm{HCl}, \mathrm{pH} 7 \cdot 5,10 \mathrm{~mm} \mathrm{MgSO}_{4}$, gelatin $0.0001 \%$ ), and two-to-three drops of chloroform. Plaque purification was performed by the above method.

\section{Fusion protein and immunblot preparation}

E. coli XL1-Blue cells were infected with purified positive phage clones on $\mathrm{L}$ broth agar to give $5000 \mathrm{pfu} /$ $85-\mathrm{mm}$ plate, and incubated at $42^{\circ} \mathrm{C}$ for $4 \mathrm{~h}$. Fusion protein was induced by adding $1 \mathrm{ml}$ of $10 \mathrm{mM}$ IPTG/ plate and incubation at $37^{\circ} \mathrm{C}$ for $3.5 \mathrm{~h}$. The crude lysates were recovered by adding $0.5 \mathrm{ml}$ of lysis buffer $(\beta$-mercaptoethanol $25 \%$, SDS $10 \%, 6 \mathrm{~m}$ urea, $300 \mathrm{~mm}$ Tris- $\mathrm{HCl}, \mathrm{pH} 6.8$ ) and gently shaking the sealed plates at $37^{\circ} \mathrm{C}$ for $10-15 \mathrm{~min}$. The buffers, containing the fusion proteins, were centrifuged at $4000 \mathrm{rpm}$ for $10 \mathrm{~min}$ to remove debris and stored at $-20^{\circ} \mathrm{C}$.

Protein gel electrophoresis and immunoblotting were performed. Fusion protein samples $(75 \mu \mathrm{l})$ and Rainbow Protein Molecular Weight Markers (25 $\mu$ l; Amersham International plc) were made up to a total volume of $100 \mu \mathrm{l}$ with cracking buffer (SDS 2.6\%, 2- $\beta$ mercaptoethanol $1.3 \%$, glycerol $6 \%$, bromophenol blue $0.2 \%, 0.05 \mathrm{M}$ Tris- $\mathrm{HCl}, \mathrm{pH} 6.8$ ), and heated at $100^{\circ} \mathrm{C}$ for $3 \mathrm{~min}$. The samples were then loaded on to an acrylamide $10 \%$ slab gel, and run in a discontinuous buffer system (Protean II xi Slab Cell; BioRad Laboratories Ltd, Herts) at $80 \mathrm{~mA}$ for $3 \mathrm{~h}$. Proteins were transblotted on to nitrocellulose paper at $500 \mathrm{~mA}$ for $30 \mathrm{~min}$ (Trans-Blot Cell Model; BioRad). The nitrocellulose was blocked overnight at $4^{\circ} \mathrm{C}$ in BSA $3 \%$. Immunoblotting was performed as for the antibody screening method described above, with a 1000 -fold dilution of anti- $\beta$-galactosidase mouse monoclonal antibody (Promega) in BSA 3\% as the primary antibody, and a 4000 -fold dilution of anti-mouse polyvalent immunoglobulin-alkaline phosphatase conjugate in BSA $3 \%$ as the secondary antibody. The alkaline phosphatase stain $-660 \mu \mathrm{l}$ of nitroblue tetrazolium (NBT) $0.05 \mathrm{~g} / \mathrm{ml}$ in $\mathrm{N}, \mathrm{N}$ dimethyl formamide (DMF) $70 \%$ added to $100 \mathrm{ml}$ of $100 \mathrm{~mm} \mathrm{NaCl}, 52.6 \mathrm{~mm}$ magnesium chloride, $100 \mathrm{~mm}$ Tris-Cl, pH 9.5, buffer, before $330 \mu \mathrm{l}$ of 5-bromo-4chloro-3-indolyl phosphate (BCIP) in DMF $70 \%$, was added - was substituted for the Fast Red stain.

\section{Antigen-directed antibody selection}

Two 100- $\mu$ l volumes of resuspended $E$. coli XL1Blue cells were infected with a dilution of a high titre stock of purified positive phage on $L$ broth agar to give $5000 \mathrm{pfu} / 85-\mathrm{mm}$ plate. Phage adsorption proceeded at $37^{\circ} \mathrm{C}$ for $30 \mathrm{~min}$. The adsorption mixes were added to $2.5-\mathrm{ml}$ volumes of $\mathrm{L}$ broth agarose $0.8 \%$, mixed, and poured on to $\mathrm{L}$ broth agar plates. These plates were incubated at $42^{\circ} \mathrm{C}$ for $2.5 \mathrm{~h}$, before nitrocellulose filters $(0.45 \mu \mathrm{m}$ pore size; Sartorius), pre-soaked in $10 \mathrm{~mm}$ IPTG and dried at room temperature for at least $1 \mathrm{~h}$, were added and incubated at $37^{\circ} \mathrm{C}$ overnight. Each filter was then washed three times over a 30-min period in Tris-buffered saline $(150 \mathrm{~mm} \mathrm{NaCl}, 10 \mathrm{~mm}$ Tris- $\mathrm{HCl}, \mathrm{pH} 7 \cdot 2$ ), and blocked overnight at $4{ }^{\circ} \mathrm{C}$ in BSA $3 \%$. A 10 -fold dilution of serum in BSA $3 \%$ was added to the filters and incubated with shaking at room temperature for $3 \mathrm{~h}$. This serum was removed, defined as "the depleted serum" and stored at $4{ }^{\circ} \mathrm{C}$. The filters were washed five times over a 100 -min period with Tween 20-Tris-buffered saline $(150 \mathrm{~mm}$ $\mathrm{NaCl}, 10 \mathrm{~mm}$ Tris-HCl, pH 7.2, Tween $200.05 \%$ ), and once with salt-Tween 20 solution $(150 \mathrm{~mm} \mathrm{NaCl}$, Tween $20.05 \%$ ). The bound antibody was eluted by adding $5 \mathrm{ml}$ of glycine saline buffer $(150 \mathrm{~mm} \mathrm{NaCl}$, $200 \mathrm{~mm}$ glycine- $\mathrm{Cl}, \mathrm{pH} \mathrm{2.8)}$, and shaking at room temperature for $30 \mathrm{~min}$. The buffer was aspirated into 
a 7-ml glass bottle, containing Tris $0.04 \mathrm{~g}$, mixed, defined as "eluted antibody" and stored at $4{ }^{\circ} \mathrm{C}$. A Western blot of $S$. sobrinus MUCOB 263 was performed by the immunoblot method described above with the original serum, depleted serum and eluted antibody as the primary antibodies. The antigen was the supernate of the strain after crushing in an X-press. The secondary antibody was a 1000-fold dilution of anti-human IgM and IgG alkaline phosphatase conjugates in BSA $3 \%$, and the alkaline phosphatase stain was used.

\section{In-vivo excision of DNA insert}

A $10-\mathrm{ml}$ overnight culture of $E$. coli XL1-Blue cells grown at $37^{\circ} \mathrm{C}$ in $\mathrm{L}$ broth containing tetracycline $125 \mu \mathrm{g} / \mu \mathrm{l}$, was centrifuged at $2000 \mathrm{rpm}$ for $10 \mathrm{~min}$, resuspended in $4 \mathrm{ml}$ of $10 \mathrm{mM} \mathrm{MgSO}_{4}$ and stored at $4^{\circ} \mathrm{C}$. In a $50-\mathrm{ml}$ plastic conical tube, $200 \mu \mathrm{l}$ of the resuspended $E$. coli XL1-Blue cells, $180 \mu$ l of high titre antibody-positive phage, (c $1.78 \times 10^{8} / 85$-mm plate), and $1 \mu \mathrm{l}$ of R408 helper phage were combined and incubated at $37^{\circ} \mathrm{C}$ for $15 \mathrm{~min}$ (helper phage and $E$. coli XL1-Blue cells were from Clontech). Then, $5 \mathrm{ml}$ of $2 \times \mathrm{YT}$ media $(\mathrm{NaCl} 5 \mathrm{~g} / \mathrm{L}$, yeast extract $10 \mathrm{~g} / \mathrm{L}$, bacto-tryptone $16 \mathrm{~g} / \mathrm{L}, \mathrm{pH} 7 \cdot 0$ ) were added to the dual-infected bacteria and incubated with shaking at $37^{\circ} \mathrm{C}$ for $3 \mathrm{~h}$. The cells were killed by heating at $70^{\circ} \mathrm{C}$ for $20 \mathrm{~min}$ and ruptured by vortex mixing for $5 \mathrm{~min}$. The cells were centrifuged at $4000 \mathrm{rpm}$ for $5 \mathrm{~min}$, and the supernate containing pBluescript $\mathrm{SK}(-)$ phagemid was decanted and stored at $4^{\circ} \mathrm{C}$. The phagemid was propagated by adding $10 \mu \mathrm{l}$ of the phagemid solution to $200 \mu \mathrm{l}$ of resuspended $E$. coli XL1-Blue cells, incubating the culture at $37^{\circ} \mathrm{C}$ for $15 \mathrm{~min}$, and plating 1-, 25-, 75- and 100- $\mu$ l volumes on to $\mathrm{L}$ broth agar plates containing ampicillin $50 \mu \mathrm{g} / \mathrm{ml}$.

\section{Plasmid DNA preparation and denaturation}

The pBluescript SK $(-)$ plasmid DNA was purified from the bacterial colonies with the Magic Minipreps DNA Purification System (Promega) and alkaline denatured by the method of Maniatis et al. ${ }^{10}$ Hence, $8 \mu \mathrm{l}$ of solution containing DNA $1 \cdot 5-2 \cdot 0 \mu \mathrm{g}$, was added to $2 \mu \mathrm{l}$ of $2 \mathrm{M} \mathrm{NaOH}$, briefly vortex mixed and centrifuged, and left at room temperature for $10 \mathrm{~min}$. Three $\mu$ l of $3 \mathrm{~m}$ sodium acetate ( $\mathrm{pH} 48$ ), $7 \mu$ l of distilled water and $60 \mu \mathrm{l}$ of absolute ethanol at $-20^{\circ} \mathrm{C}$ were then added and the DNA was precipitated at $-70^{\circ} \mathrm{C}$ for $30 \mathrm{~min}$. The precipitate was pelleted by centrifugation at $13000 \mathrm{rpm}$ for $1 \mathrm{~min}$, washed with ethanol $70 \%$ at $-20^{\circ} \mathrm{C}$ and vacuum-dried. The dried pellets were stored at $-20^{\circ} \mathrm{C}$.

\section{DNA sequencing}

DNA sequencing was performed by the two-step chain-termination method, with Sequenase Version 2.0 (Cambridge Bioscience). The annealing step was carried out at $66^{\circ} \mathrm{C}$ for $2 \mathrm{~min}$, the labelling at $22^{\circ} \mathrm{C}$ for $4 \mathrm{~min}$ and the termination at $38^{\circ} \mathrm{C}$ for $5 \mathrm{~min}$. Areas containing secondary structure were resolved by the substitution of dITP for dGTP. Sequencing reactions were run on acrylamide $6 \%$ gels, for $11,8,5$ and $2 \mathrm{~h}$ at $46^{\circ}-51^{\circ} \mathrm{C}$.

\section{Subcloning with the TA cloning ${ }^{(\text {(따) })}$ system}

The phagemid clone did not carry the $5^{\prime}$ end of the cloned gene, therefore it was decided to subclone the $5^{\prime}$ end by polymerase chain reaction (PCR), followed by TA Cloning. The following PCR reagents were added to each of three tubes containing $0,0.7$ and $1.8 \mu \mathrm{g}$ of $S$. sobrinus MUCOB 263 genomic DNA, with distilled water added to give a total volume of $64 \cdot 3 \mu \mathrm{l}: 5 \cdot 3 \mu \mathrm{l}$ of Primer 1 (CAGTCTCCGTCCCAACGACTGCG), $0 \cdot 1 \mu \mathrm{g} / \mu \mathrm{l}, 4 \cdot 4 \mu \mathrm{l}$ of Primer 2 (GCTCCTCTTGTGACATGGTC), $0 \cdot 1 \mu \mathrm{g} / \mu \mathrm{l}, 10 \mu \mathrm{l}$ of $10 \times$ Taq buffer (Northumbria Biologicals Ltd, Northumberland; nbl); and $16 \mu \mathrm{l}$ of dNTP (12.5 $\mu \mathrm{l}$ each of dATP, dGTP, dCTP, dTTP; Promega, added to $950 \mu 1$ of de-ionised water). Then, $60 \mu$ of mineral oil was carefully layered on top of the PCR reactions, the DNA was denatured at $95^{\circ} \mathrm{C}$ for $10 \mathrm{~min}$, and 2.5 Weiss units of Taq (nbl) were added. The PCR conditions were: $94^{\circ} \mathrm{C}$ for $1.5 \mathrm{~min}$, $50^{\circ} \mathrm{C}$ for $1.5 \mathrm{~min}$ and $72^{\circ} \mathrm{C}$ for $3 \mathrm{~min}$ for 30 cycles, before a final long extension of $72^{\circ} \mathrm{C}$ for $10 \mathrm{~min}$. The PCR products $(30 \mu \mathrm{l})$ were run on a TBE $0.8 \%$ gel at $50 \mathrm{~V}$ for $2 \mathrm{~h}$, alongside $4 \mu \mathrm{l}$ of EcoRI-Hind III cut lambda DNA markers (nbl).

Insert DNA was subcloned with the TA Cloning System Version 1.3 (InVitrogen Corporation, British Biotechnologies Ltd, Oxon) as specified in the manufacturer's protocol. Overnight, $12^{\circ} \mathrm{C}$ ligation reactions containing $3.0 \mu \mathrm{l}$ of a four-fold dilution, in distilled water, of the $0 \cdot 7-\mu \mathrm{g}$ PCR reaction, $4.7 \mu \mathrm{l}$ of a doubling dilution of the $0.7-\mu \mathrm{g}$ PCR reaction and a negative control were performed. In the transformation, white recombinant colonies were picked after overnight incubation at $37^{\circ} \mathrm{C}$ and twice replated on kanamycin $(50 \mu \mathrm{g} / \mathrm{ml}) / 5$-bromo-4-chloro-3-indolyl $\beta$-D-galactopyranoside (X-Gal; $25 \mu \mathrm{l}$ of $40 \mathrm{mg} / \mathrm{ml}$ solution/ plate) to achieve pure and stable subclones.

Plasmid DNA was obtained, purified, denatured and sequenced as described above.

\section{Southern blotting}

Five restriction enzyme digests ( $P$ st I, SacI, Sau3AI, $E c o \mathrm{RI}$, and BamHI) of $S$. sobrinus genomic DNA were probed with $\left[\alpha^{32} \mathrm{P}\right]$ dCTP-labelled, EcoRI-digested plasmid subclone DNA. Briefly, genomic DNA $(5 \mu \mathrm{g})$ was digested overnight at $37^{\circ} \mathrm{C}$ and the digest fragments were separated on a TBE agarose $1 \%$ gel, run at $50 \mathrm{~V}$ for $2.5 \mathrm{~h}$. The DNA was nicked by UV irradiation for $5 \mathrm{~min}$, denatured in $0.5 \mathrm{M} \mathrm{NaOH}$ for 35 min (changing the solution once), and transferred to a nylon membrane (Hybond-N Nylon, 0.45- $\mu \mathrm{m}$, hybridisation transfer membrane; Amersham) in 
$10 \times \operatorname{SSC}(1.5 \mathrm{M} \mathrm{NaCl}, 0.15 \mathrm{M}$ tri-sodium citrate, pH 7.0) by means of Model 785 Vacuum Blotter (BioRad) operated for $2 \mathrm{~h}$. The DNA was fixed to the membrane by UV irradiation for $5 \mathrm{~min}$. Prehybridisation was performed at $68^{\circ} \mathrm{C}$ for $1.5 \mathrm{~h}$ in a hybridisation oven (Appligene, Chester-le-Street, Durham). The pre-hybridisation solution was $5 \times$ Denhardts solution, $6 \times$ SSC and SDS $0.5 \%$ in distilled water, and contained $50 \mu \mathrm{l}$ of salmon testes DNA (Sigma) $10 \mathrm{mg} / \mathrm{ml}$, which had been sonicated, denatured and pre-boiled at $100^{\circ} \mathrm{C}$ for $3 \mathrm{~min}$ before use.

The subcloned DNA was digested with EcoRI at $37^{\circ} \mathrm{C}$ for $2 \mathrm{~h}$. The insert DNA was separated from the TA vector arms on a TAE low melting point $0.8 \%$ gel at $20 \mathrm{~V}$ overnight and excised from the gel. This probe DNA was prepared with the Prime-a-Gene Labelling System (Promega), and incubated at room temperature for $1.5 \mathrm{~h}$. The reaction was terminated by heating at $100^{\circ} \mathrm{C}$ for $2 \mathrm{~min}$. The probe was purified by passing it through a 1-ml Sephadex G-50 DNA Grade (Fine) column (Pharmacia Ltd, Pharmacia LKB, Biotechnology Division, Milton Keynes) before being added to the pre-hybridisation solution. Hybridisation was performed overnight at $68^{\circ} \mathrm{C}$.

The following washes were performed: three 2-min washes at room temperature with SDS $0.1 \%, 2 \times$ SSC solution; two 1 -h washes with SDS $0.1 \%, 2 \times$ SSC solution at $68^{\circ} \mathrm{C}$; and two 1 -h washes with SDS $0.1 \%$, $0.5 \times \mathrm{SSC}$ solution at $68^{\circ} \mathrm{C}$. The autoradiograph was developed after incubation overnight at $-70^{\circ} \mathrm{C}$.

\section{DNA homology study}

Comparison of the $S$. sobrinus DNA sequence with the EMBL database was performed on Seqnet with the ISIS package SWEEP, ${ }^{11}$ and the alignment was achieved with the GCG program PILEUP. ${ }^{12}$

\section{Results}

\section{Antibody screening and fusion protein preparation}

Six antibody-positive clones were isolated and purified from the 60000 pfu initially screened with serum from a patient with culture-positive endocarditis (CPE). All six clones produced a fusion protein of c. $185 \mathrm{kDa}$ apparent mol. wt. Fusion protein production was induced in the presence of IPTG and not without it (fig. 1).

Antigen-directed antibody selection showed that the cloned, expressed sequence contained epitopes shared by $S$. sobrinus, as the eluted antibody bound to the 190-kDa antigen (fig. 1).

\section{Southern blotting}

One phage clone was chosen and the insert was subcloned by the in-vivo excision method (Clontech). Southern blotting of this plasmid subclone with five

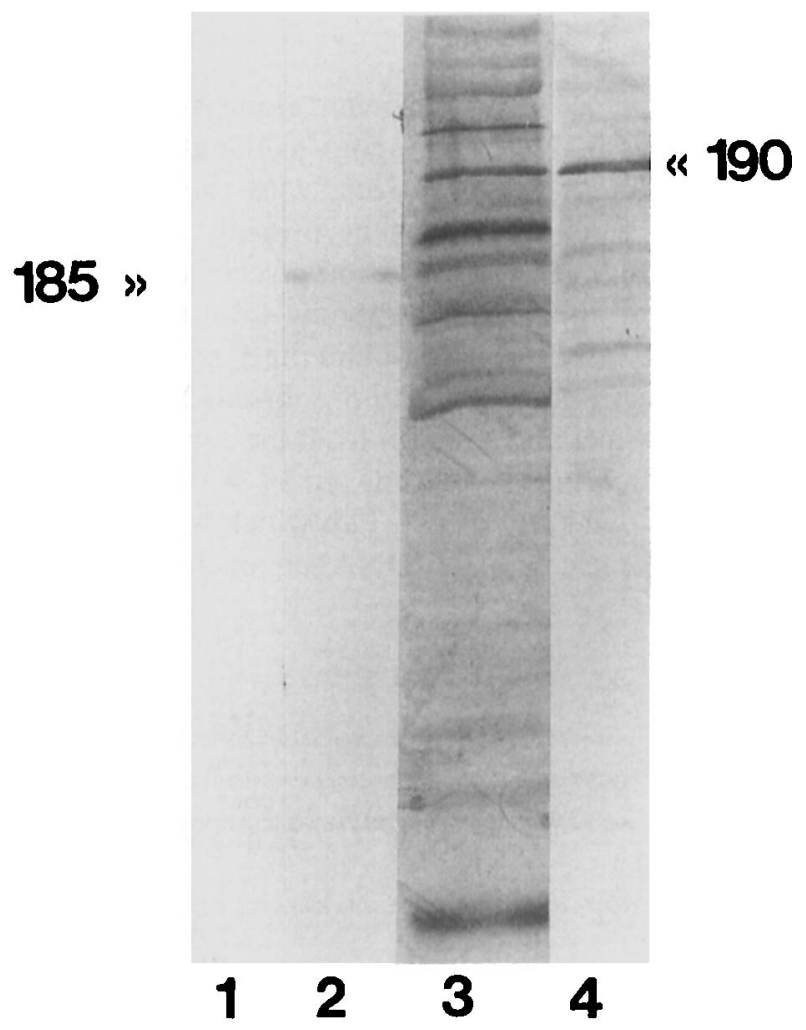

Fig. 1. Tracks 1 and 2, fusion protein production in the absence and presence of IPTG, respectively; 3 , an immunoblot of S. sobrinus MUCOB 263 with serum from a patient with endocarditis; 4 , èluted antibody.

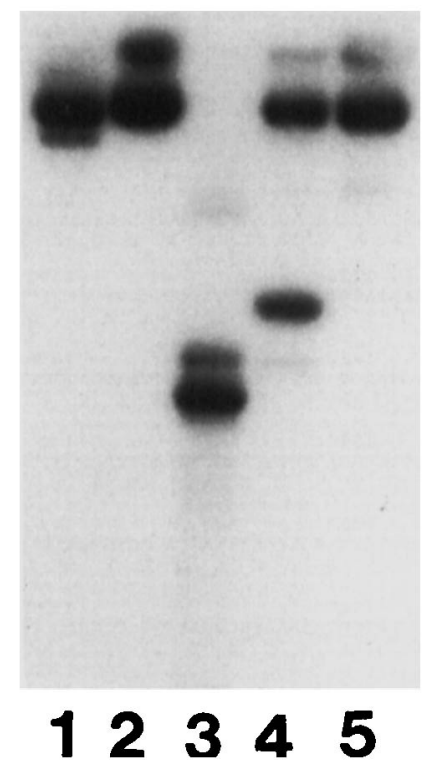

Fig. 2. Tracks 1-5 show $S$. sobrinus genomic DNA digested with PstI, SacI, Sau3AI, EcoRI and BamHI, respectively. The blot was probed with the $4 \cdot 7-\mathrm{kb}$ insert encoded by the pBluescript SK(-) phagemid.

restriction endonuclease digests of $S$. sobrinus MUCOB 263 genomic DNA produced the patterns shown in fig. 2. This blot confirmed that the clone contained streptococcal DNA originating from $S$. sobrinus MUCOB 263. 


\section{$D N A$ sequencing}

The sequence of the phagemid clone is shown in fig. 3. This was highly homologous to the gene encoding the $S$. sobrinus SpaA antigen, with the first $275 \mathrm{bp}$ from the $5^{\prime}$ end of the gene missing. This finding agreed with the size of the fusion protein and the crossreaction of the eluted antibody with the $190-\mathrm{kDa}$ antigen of $S$. sobrinus. To obtain the $5^{\prime}$ end of the gene, two primers were made-an S. sobrinus MUCOB 263 internal primer and a primer from the conserved 5 ' end of the $S$. sobrinus spaA gene. In PCR, these primers produced one band of $c .0 .3 \mathrm{~kb}$ which was subcloned into the TA vector. After DNA sequencing, the $0 \cdot 3-\mathrm{kb}$ sequence was added to that obtained from the phagemid clone.

\section{DNA homology study}

The cloned gene showed $99 \cdot 2 \%$ homology to the spaA gene of $S$. sobrinus, $91.4 \%$ homology to the gene encoding $S$. sobrinus antigen I, 68.4\% homology to the pac gene of $S$. mutans, $67.6 \%$ homology to the spaP gene of $S$. mutans, and $40.0 \%$ homology to the $S$. sanguis agglutinin receptor gene. ${ }^{13}$ This degree of homology implies that the protein is a member of the surface protein family first identified in studies of dental caries. Fig. 3 shows that the protein contains the

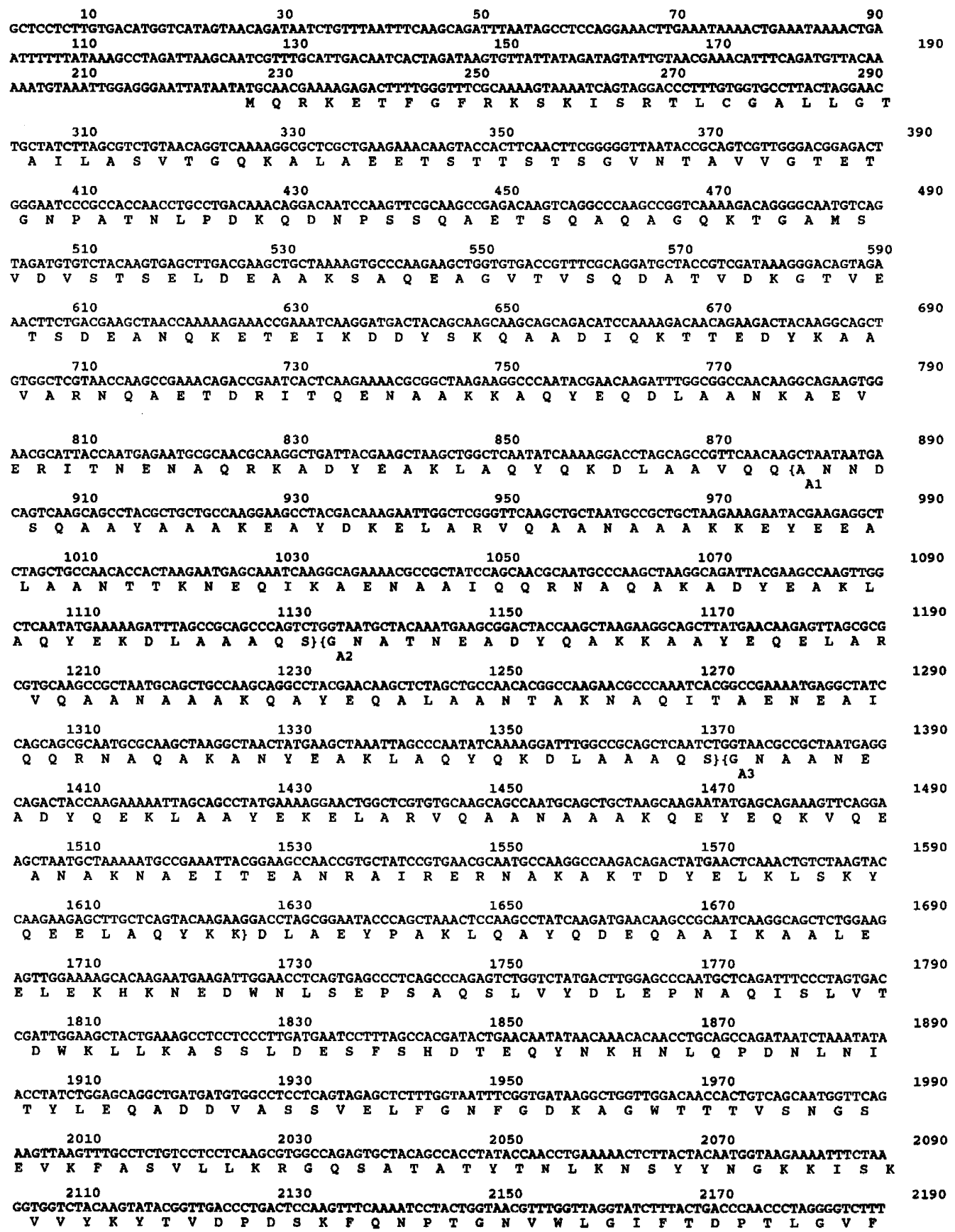

Fig. 3. See p. 335 for legend. 


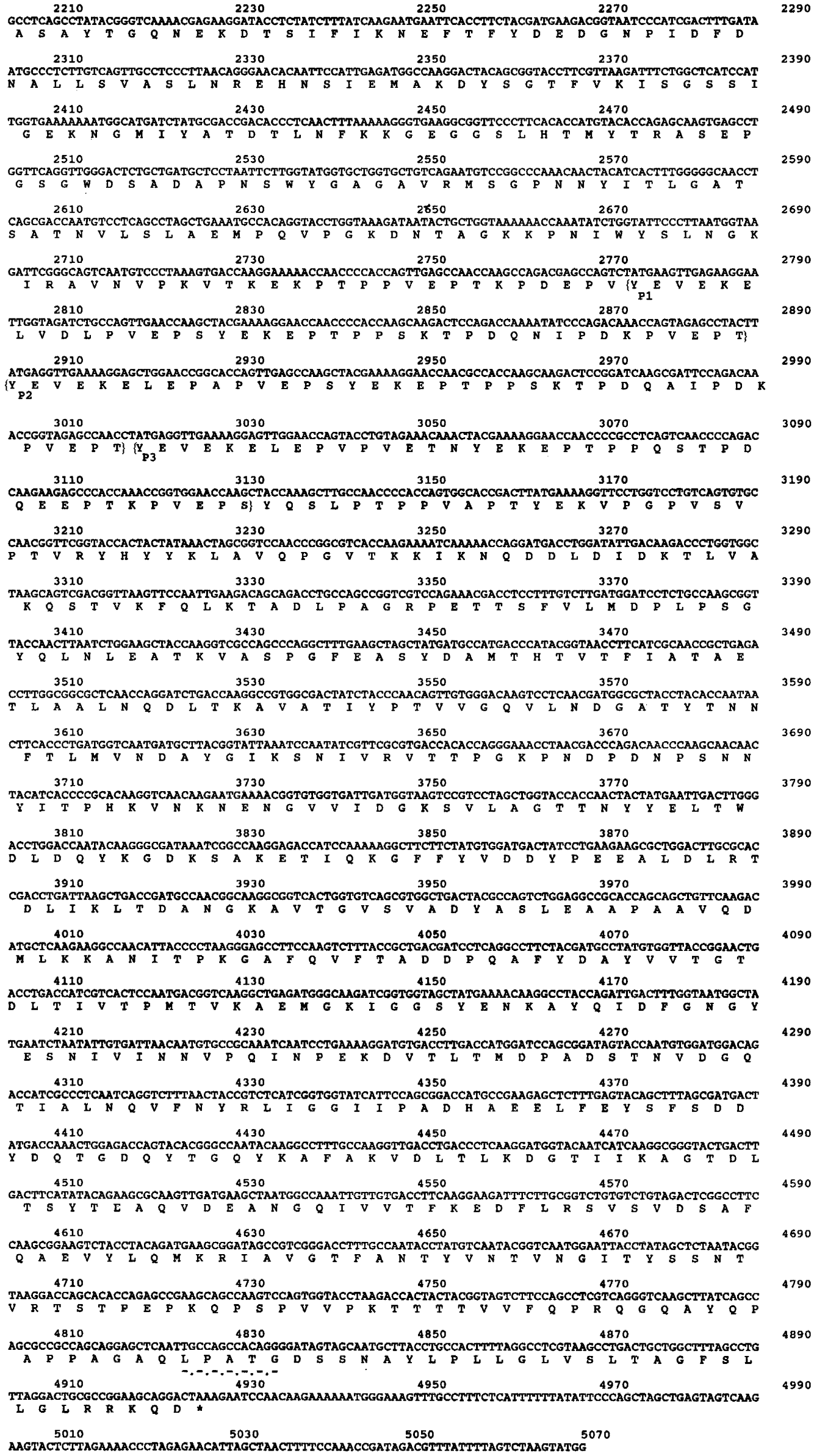

Fig. 3. S. sobrinus MUCOB 263 DNA sequence and the deduced amino-acid sequence. The LPXTG signal sequence for the postulated membrane anchor attachment site is indicated by $(-\cdot-)$, and the $\mathrm{A}$ - and $\mathrm{P}$-regions are bracketed $(\{\})$. 
3-tandem repeated alanine and proline regions described by Brady et al., ${ }^{14}$ and the LPXTG signal sequence, postulated by Kelly et al. ${ }^{15}$ to be the glycoprotein membrane anchor attachment site. The wall-spanning and leader regions, described by LaPolla et al. ${ }^{16}$ are also present in fig. 3, but not highlighted.

\section{Discussion}

This study demonstrated that the $190-\mathrm{kDa}$ immunodominant endocarditis-specific antigen Esa of $S$. sobrinus MUCOB 263 was $99 \cdot 2 \%$ homologous to the SpaA antigen of $S$. sobrinus. ${ }^{16}$ This finding cast doubt on the classification of the strain previously published as S. mutans MUCOB 263. Re-testing of the organism by Professor D. Bratthall identified the strain as $S$. sobrinus, on the basis of glucose and mannitol fermentation and failure to ferment acetyl-glucose-amine and arbutine. This strain is now referred to as $S$. sobrinus MUCOB 263. The sequence also showed $68.4 \%$ homology to $S$. mutans antigen $\mathrm{I} / \mathrm{II} .^{3}$ This antigen has been linked to the initial sucrose-independent attachment of $S$. mutans to tooth surfaces and is thought to function as an adhesin. ${ }^{17}$ Local passive immunisation with monoclonal antibodies against $S$. mutans antigen I/II prevented colonisation with S. mutans in man. ${ }^{18}$

Re-classification of the S. sobrinus MUCOB 263 isolate raised questions concerning the identity of the streptococcal isolate cultured from the patient with $\mathrm{CPE}$ whose serum was used for antibody screening of the lambda ZAPII library. Unfortunately, the original organism was no longer available for further identification. However, both $S$. mutans and $S$. sobrinus belong to the mutans group of streptococci, and are the most closely related bacteria within this group. Moreover, this paper illustrates that the Esa protein, together with the S. sobrinus SpaA and S. mutans PAc proteins, are so closely related that an antibody response raised against one organism would probably cross-react with the other. Further work is required to study cross-reactions between sera from patients with CPE with different viridans streptococci.

\section{References}

1. Clark I, Burnie JP. Immunoblotting and culture positive endocarditis. $J$ Clin Pathol 1991 ; 44: 152-156.

2. Russell RRB. Wall-associated antigens of Streptococcus mutans. J Gen Microbiol 1979; 114: 109-115.

3. Russell MW, Bergmeier LA, Zanders ED, Lehner T. Protein antigens of Streptococcus mutans: purification and properties of a double antigen and its protease-resistant component. Infect Immun 1980; 28: 486 493.

4. Hughes M, Machardy SM, Sheppard AJ, Woods NC. Evidence for an immunological relationship between Streptococcus mutans and human cardiac tissue. Infect Immun 1980; 27 576-588.

5. Demuth DR, Golub EE, Malamud D. Streptococcal-host interactions. Structural and functional analysis of a Streptococcus sanguis receptor for human salivary glycoprotein. J Biol Chem 1990; 265: 7120-7126.
The findings presented in this paper are consistent with the immunodominance of the related $S$. mutans antigen I/II in endocarditis. Elevated levels of antibody against biochemically purified $S$. mutans antigen I/II has been shown by ELISA in five patients with $S$. mutans endocarditis. ${ }^{19}$ This approach has problems, in that it is labour intensive to prepare the protein and every preparation is subject to batch-to-batch variation. The present cloning strategy will tend to detect linear epitopes that could be chemically synthesised. The size of the cloned protein was too large to do this but the positive clone will be re-cloned, following restriction endonuclease digestion, to ascertain the position and sequence of the key epitopes. The antigen could also be used as an expressed fusion protein in an indirect ELISA. This has a drawback, in that antibody against the $\beta$-galactosidase part of the fusion protein will also be detected, but this approach has worked for another immunodominant antigen specific to Enterococcus faecalis endocarditis. ${ }^{20}$ A possible link ${ }^{4,6,21,22}$ between the $S$. mutans antigen I/II and the production of human heart-specific antibodies has now been discounted and shown to be associated with a 62 $\mathrm{kDa}$ membrane protein containing myosin-like epitopes. ${ }^{23}$

The cloned protein also showed $40.0 \%$ homology to the agglutinin receptor gene from $S$. sanguis. ${ }^{13}$ A probe from the $3^{\prime}$ region of the gene which encoded residues 857-1207 of $S$. mutans antigen I/II has been shown previously to hybridise with DNA from a range of $\alpha$ haemolytic streptococci including $S$. sanguis, $S$. intermedius, $S$. anginosus, $S$. gordonii and $S$. oralis. ${ }^{17}$

These cross-reactivities may mean that the presence of a high level of antibody against the cloned antigen does not give a specific diagnosis of endocarditis due to either $S$. mutans or $S$. sobrinus. It may act as a wider test for endocarditis due to a range of $\alpha$-haemolytic streptococci. This is of little clinical importance, as all of these bacteria are sensitive to standard therapy with benzylpenicillin and gentamicin.

This work was funded by a British Heart Foundation Fellowship. We thank Professor D. Bratthall, WHO Collaborating Centre, Sweden, for identifying S. sobrinus MUCOB 263.

6. Forester H, Hunter N, Knox KW. Characteristics of a high molecular weight extracellular protein of Streptococcus mutans. J Gen Microbiol 1983; 129: 2779-2788.

7. Okahashi N, Sasakawa C, Yoshikawa M, Hamada S, Koga T. Molecular characterization of a surface protein antigen gene from serotype c Streptococcus mutans, implicated in dental caries. Mol Microbiol 1989; 3: 673-678.

8. Lehner T, Russell MW, Caldwell J, Smith R. Immunization with purified protein antigens from Streptococcus mutans against dental caries in rhesus monkeys. Infect Immun $1981 ; 34$ : 407-415.

9. Chassy BM. A gentle method for the lysis of oral streptococci. Biochem Biophys Res Commun 1976; 68: 603-608.

10. Sambrook J, Fritsch EF, Maniatis T. Molecular cloning-a laboratory manual, 2nd edn. Cold Spring Harbor, NY, Cold Spring Harbor Laboratory Press. 1989.

11. Protein Engineering Club Database Group. A protein sequence/structure database. Nature 1988; 335: 745-746. 
12. Devereux J, Haeberli P, Smithies O. A comprehensive set of sequence analysis programs for the VAX. Nucleic Acids Res 1984 ; 12 : 387-395.

13. Demuth DR, Davis CA, Corner AM, Lamont RJ, Leboy PS, Malamud D. Cloning and expression of a Streptococcus sanguis surface antigen that interacts with a human salivary agglutinin. Infect Immun 1988; 56: 2484-2490.

14. Brady LJ, Crowley PJ, Ma JK-C et al. Restriction fragment length polymorphisms and sequence variation within the spaP gene of Streptococcus mutans serotype c isolates. Infect Immun 1991; 59: 1803-1810.

15. Kelly C, Evans P, Ma JK-C et al. Sequencing and characterization of the $185 \mathrm{kDa}$ cell surface antigen of Streptococcus mutans. Arch Oral Biol 1990; 35 Suppl: 33S-38S.

16. LaPolla RJ, Haron JA, Kelly CG et al. Sequence and structural analysis of surface protein antigen I/II (SpaA) of Streptococcus sobrinus. Infect Immun 1991; 59: 2677-2685.

17. Ma JK-C, Kelly CG, Munro G, Whiley RA, Lehner T. Conservation of the gene encoding streptococcal antigen I/II in oral streptococci. Infect Immun 1991; 59: 26862694.
18. Ma JKC, Hunjan M, Smith R, Lehner T. Specificity of monoclonal antibodies in local passive immunisation against Streptococcus mutans. Clin Exp Immunol 1989; 77 : 331-337.

19. Russell MW, Wu HY, White PL, Kilian M, Henrichsen J. Serum antibody responses to Streptococcus mutans antigens in humans systemically infected with oral streptococci. Oral Microbiol Immunol 1992; 7: 321-325.

20. Burnie JP, Clark I. Diagnosing endocarditis with the cloned $112 \mathrm{kDa}$ antigen of Enterococcus faecalis. $J$ Immunol Methods 1989; 123: 217-225.

21. Ferretti JJ, Shea C, Humphrey MW. Cross-reactivity of Streptococcus mutans antigens and human heart tissue. Infect Immun 1980; 30: 69-73.

22. Russell RRB. Distribution of cross-reactive antigens $A$ and $B$ in Streptococcus mutans and other oral streptococci. J Gen Microbiol 1980; 118: 383-388.

23. Ayakawa GY, Bleiweis AS, Crowley PJ, Cunningham MW. Heart cross-reactive antigens of mutans streptococci share epitopes with group A streptococci and myosin. J Immunol $1988 ; 140: 253-257$. 